\title{
Profitability management of tourism sector in AP Vojvodina
}

\author{
Vera Mirović \\ University of Novi Sad, Faculty of Economics in Subotica, Subotica, Serbia \\ https://orcid.org/0000-0002-1465-4692 \\ Branimir Kalaš \\ University of Novi Sad, Faculty of Economics in Subotica, Subotica, Serbia \\ https://orcid.org/0000-0002-9141-7957 \\ Nada Milenković \\ University of Novi Sad, Faculty of Economics in Subotica, Subotica, Serbia \\ https://orcid.org/0000-0001-9810-3021

\section{Jelena Andrašić} \\ University of Novi Sad, Faculty of Economics in Subotica, Subotica, Serbia \\ https://orcid.org/0000-0003-3941-1184
}

\begin{abstract}
Tourism plays an increasingly important role in the economic flows of each country. Recognizing the tourist potential of AP Vojvodina is an important task for the creators of the economic policy of our country. In order to make a favourable tourism environment with quality tourist content and products, it is necessary for tourist entities to operate stably and successfully. The aim of this paper is to highlight the importance of financial performance of firms in tourism sector in terms of profitability. The subject of the paper is to analyse the effects of internal factors on profitability level of 3456 firms in tourism sector in AP Vojvodina for the period 2015-2019. The results of the analysis indicate that observed firms were profitable during the analysed period, where average ROA was $1.81 \%$ and average ROE was $3.4 \%$. Empirical analysis shows that internal factors such as firm size, sales revenue, earnings before interest and taxes and financial stability have positive impact on profitability, while liquidity and debt negatively affect the profitability of firms in tourism sector.
\end{abstract}

\section{Keywords}

profitability, tourism, sector, AP Vojvodina

\section{Introduction}

The tourism sector has a significant role as a source of economic growth in most economies in the world (Dimitropoulos, 2017). Namely, tourism sector represents an important potential of any national economy where a positive trend in tourism revenue has a significant role in realizing macroeconomic goals and social welfare (Milenković, Andrašić \& Kalaš, 2017). Rodríguez-Díaz and Rodríguez-Díaz (2018) indicate that governments favour this sector because of its significant contribution to the gross national product. Since an ever-increasing number of people wants to travel, primarily in foreign country, tourism manifests one of the fastestgrowing industry in the world (Pavković, Jević, Jević, Nguyen \& Sava, 2021). Tourism industry is among the world fastest growing industries, generating substantial economic benefits, as well as contributing to employment and stimulating investments (Dimitrić, Tomas Živković, \& Blecich, 2019). Similarly, Bazargani and Kiliç (2021) argue that this sector is one of the main sectors of the world economy that contributes to employment, higher revenue level and promotion of economic prosperity. Sharpley (2020) highlighted the position of tourism sector in economic structure and concept of sustainable development based on the premise of economic 
growth. Tourism is an important economic engine and enables socioeconomic development, generating employment opportunities (Usmani, Akram \& Praveen, 2020).

The structure of this paper is as follows. After the introduction, there is a literature review which includes previous theoretical and empirical studies that have analysed profitability determinants in the tourism sector. The second part presents the characteristics and state of tourism sector in AP Vojvodina from the aspect of tourist arrivals, number of employees and financial performance of the observed firms. The third segment indicates data and methodology, and includes variables and econometric procedures for adequately created regression model. The last segment reports empirical results in terms of estimating the impact of internal factors on profitability in tourism sector of AP Vojvodina for the period 2015-2019.

\section{Literature review}

There are many empirical studies that have analysed profitability determinants in tourism sector (Agiomirgianakis, Magoutas \& Sfakianakis, 2013; Ben Aissa \& Goaied, 2016; Mijić \& Jakšić, 2017; Alarussi \& Alhaderi, 2018). Profitability is often measured by return on assets (Macas Nunes, Serrasqueiro \& Sequeira, 2009; Stierwald, 2010; Skuflić \& Mlinarić, 2015; Tan, 2017, Dimitrić et al., 2019).

Agiomirgianakis et al. (2013) analysed the profitability of 134 hotels in Greece for the period 2006-2010. Their results identified size and leverage as two significant factors that have positive impact on profitability of firms in tourism sector. Ben Aissa and Goaied (2016) investigated 27 Tunisian hotels for the period 2000-2010 and their results showed positive relationship between efficiency and profitability for the observed period. Further, their analysis indicate that debt has positive impact on profitability, while size negatively affect the profitability measured by ROA. Mijić and Jakšić (2017) investigated the relationship between indebtedness and profitability for companies in the Republic of Serbia for the period 2009-2013. Their findings showed negative correlation between these variables. Alarussi and Alhaderi (2018) investigated 120 companies listed on Bursa Malaysia from 2012 to 2014. Their findings showed a strong positive relationship between size, company efficiency and profitability, as well as a negative relationship between debt to leverage ratio and profitability. Finally, variable liquidity has no significant impact on profitability of the analysed firms in Malaysia for the observed period. Lado-Sestayo, Otero-González, Vivel-Búa \& Martorell-Cunill, (2016) showed that profitability depends largely on the market structure and the level of demand of the tourist destination. Further, Lado-Sestayo and Vivel-Búa (2018) identified that higher profitability of hotels depend on characteristics, location, competitive environment and tourist destination. Menicucci (2018) researched 2366 hotels in Italy for the period 2008-2016 and found that business model, ownership structure and financial structure affect the profitability. Also, factors such as size, location, accommodation and internationalization have positive impact on profitability level.

\section{Characteristics and state of tourism sector in AP Vojvodina}

Tourism industry in Serbia and region countries such as Croatia, Hungary, Romania and Slovenia reflect great interest in business tourism development (Kalaš, Mirović \&Pavlović, 2019).

Bearing in mind that tourism development requires natural resources, sustained environment, cultural and historic heritage, Serbia has a chance to improve competitive tourism position on the world level by developing tourism products (Pavlović \& Đeri, 2016). For example, Markus, Perovic, Pekovic \&Popovic (2019) indicate that from the earliest stages of tourism development, sport-recreational activities have a great role and significance in creating and designing tourist services. On the other hand, Moric, Pekovic, Vukčević, Perović \& Grisbeck (2021) highlighted the importance of cultural tourism and community engagement. Development model of AP Vojvodina should focus on (Provincial Secretariat for Economy and Tourism, 2018):

a) agricultural production focused on high quality wine and other products with high added value in order to enable better position in tourism market at global level; b) develop brand elements, system of quality labels and protection mechanisms for all possible products in parallel; c) initiate urban rehabilitation and development of Novi Sad and other major urban centres of Vojvodina; d) improve the product of culture, presentation of cultural contents by applying modern technologies, and use national and EU funds; e) further develop the infrastructure and marketing of the navigable flows of the Danube, Sava, Tisa, Tamiš and canal network, because of their vitality for traffic access. 


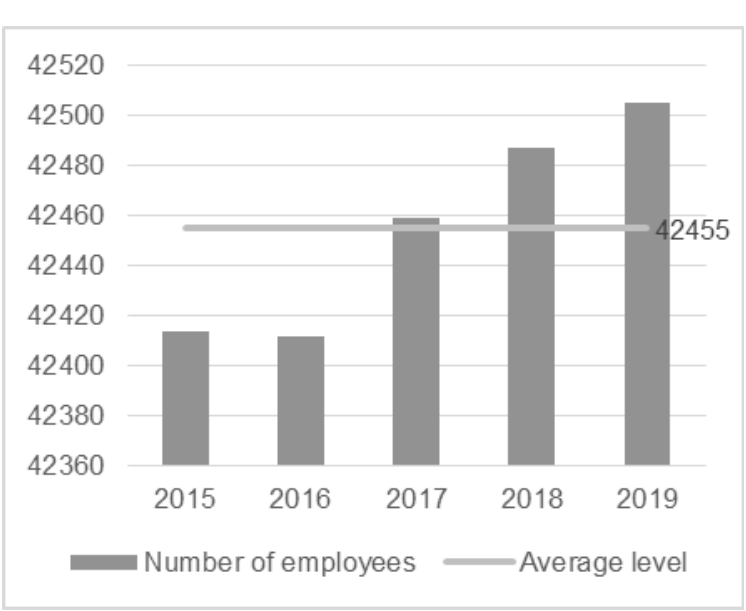

Figure 1 The number of employees in tourist sector in AP Vojvodina

Source: the authors

The average number of employees in tourist sector in AP Vojvodina is 42455 during the analyzed period 2015-2019. In last five years, the number of employees is increased by only 91 which is insignficant growth during the observed period.

Table 1 Tourist arrivals at regional level

\begin{tabular}{c|c|c|c|c}
\hline $\begin{array}{c}\text { Tourist } \\
\text { arrivals }\end{array}$ & $\begin{array}{c}\text { Belgrade } \\
\text { region }\end{array}$ & $\begin{array}{c}\text { Vojvodina } \\
\text { region }\end{array}$ & $\begin{array}{c}\text { Sumadija } \\
\text { and } \\
\text { Western } \\
\text { Serbia } \\
\text { region }\end{array}$ & $\begin{array}{c}\text { South } \\
\text { and } \\
\text { East } \\
\text { Serbia } \\
\text { region }\end{array}$ \\
\hline Domestic & 201770 & 287419 & 950289 & 403954 \\
\hline Foreign & 1056578 & 274238 & 309396 & 206339 \\
\hline Total & 1258348 & 561657 & 1295685 & 610293 \\
\hline
\end{tabular}

Analyzing the number of tourist arrivals according to the regional approach, it is noticeable that the largest number of tourists visited Belgrade (1258348) in 2019. The next region is Šumadija and Western Serbia with 1295685 tourists, while the lowest number of tourists visited Vojvodina in the observed year. After presenting the position of tourist sector at the national level, the research analyzes two sector in tourism of AP Vojvodina: sector 55 (accommodation) and sector 56 (serving and preparing food and beverages).

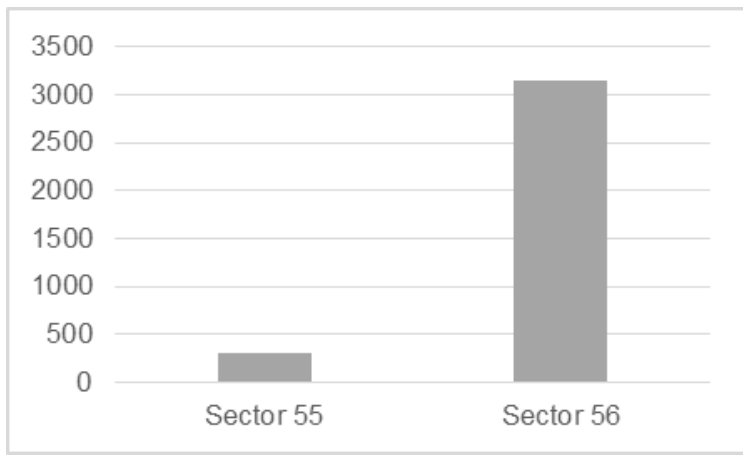

Figure 2 The number of employees by tourist sector structure AP Vojvodina Source: the authors

Based on observed 3456 firms from tourism sector in AP Vojvodina, we can notice that sector 56 accounts for 3148 firms or $91.09 \%$ of the total number of firms in tourist sector.

\subsection{Financial performance of tourism sector in AP Vojvodina}

Profitability indicators are used to measure the ability of sale revenues and assets of the firms to achieve a positive business result. Profitability can be measured by gross profit margin, net profit margin, as well as return on assets and return on capital. Return on assets is an indicator of managerial efficiency that defines earning ability related to investment in total assets (Andrašić, Mijić, Mirović, \& Kalaš, 2018).

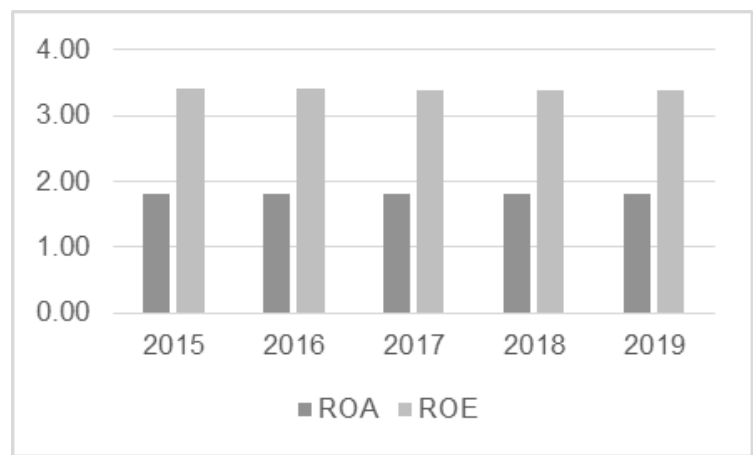

Figure 3 Profitability indicators of tourism sector in AP Vojvodina

Source: the authors

In order to define profitability level of firms from tourism sector in AP Vojvodina, we measured ROA and ROE as two most important indicators of profitability. The results of analysis manifest stable trend of both indicators, where ROA and ROE were at level of $1.81 \%$ and $3.4 \%$. 


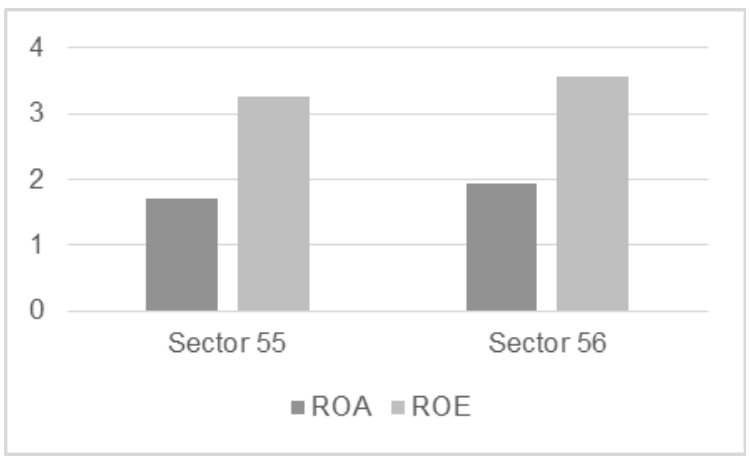

Figure 4 Comparative analysis of profitability in tourism sector in AP Vojvodina Source: the authors

Figure 4 shows a comparative overview of companies from sector 55 and companies from sector 56 from the aspect of average profitability level. As it can be seen, firms from sector 56 were more profitable with average ROA of $3.56 \%$ and average ROE of $1.93 \%$. On the other hand, firms from sector 55 had lower average return on assets and return on capital during the observed period.

\section{Methodology and data}

This study analyses 3456 firms from tourist sector in AP Vojvodina from 2015 to 2019. The sample of tourist sector includes firms from sector 55 (accommodation) and firms from sector 56 (serving and preparing food and beverages) which have the obligation to disclose their financial statements publicly.

Table 2 Variable definition

\begin{tabular}{|c|c|c|}
\hline Variable & Note & Calculation \\
\hline \multicolumn{3}{|c|}{ Dependent variable } \\
\hline $\begin{array}{ll}\text { Return } & \text { on } \\
\text { assets } & \\
\end{array}$ & ROA & Net income/Total asset \\
\hline \multicolumn{3}{|c|}{ Independent variables } \\
\hline Firm size & SIZE & $\begin{array}{c}\text { Logarithmic value of the } \\
\text { total assets }\end{array}$ \\
\hline Sales revenue & SR & $\begin{array}{c}\text { (Sales revenue }{ }_{t}-\text { Sales } \\
\text { revenue } t-1) / \text { Sales } \\
\text { revenue } t-1\end{array}$ \\
\hline $\begin{array}{l}\text { Earnings } \\
\text { interest and } \\
\text { taxes }\end{array}$ & EBIT & $\begin{array}{l}\text { Operating revenues - } \\
\text { Operating expenses }\end{array}$ \\
\hline Current liquidity & CL & $\begin{array}{c}\text { Current assets/Current } \\
\text { liabilities }\end{array}$ \\
\hline Debt & DBT & Total liabilities/Capital \\
\hline $\begin{array}{l}\text { Financial } \\
\text { stability }\end{array}$ & FS & $\begin{array}{c}\text { Long-term assets/Long- } \\
\text { term debts }\end{array}$ \\
\hline
\end{tabular}

The model can be presented as:

$$
\begin{gathered}
R O A t=\beta_{0}+\beta_{1} S I Z E_{t}+\beta_{2} S R_{t}+\beta_{3} E B I T_{t}+\beta_{4} C L_{t}+ \\
\beta 5 D B T t+\beta 6 F S t \ldots+e t
\end{gathered}
$$

where:

ROA - return on assets; SIZE - firm size; SR - sales revenue; EBIT - earnings before interest and tax; CL - current liquidity; DBT - debt; FS financial stability; $\beta 0$ - the constant term; $\beta$ - the coefficient of the independent variables; $\mathrm{e}-$ the error term of the equation

\section{Empirical analysis and results}

Before regression analysis, the study includes descriptive statistics of explanatory variables, as well as correlation analysis in order to determine the character and intensity of their relationship.

Table 3. Descriptive statistics

\begin{tabular}{c|c|c|c|c}
\hline Variable & Mean & Maximum & Minimum & $\begin{array}{l}\text { Std. } \\
\text { Dev. }\end{array}$ \\
\hline SIZE & 28225 & 1288963 & 10 & 8.433 \\
\hline SR & 16921.5 & 744814.01 & 4 & 4.577 \\
\hline EBIT & 673.744 & 134972.52 & -64495.01 & 7.156 \\
\hline CL & 1.951 & 4.692 & 0.833 & 6.166 \\
\hline DBT & 0.621 & 1.122 & 0.464 & 0.535 \\
\hline FS & 0.200 & 0.719 & 0.006 & 2.813 \\
\hline ROA & 1.81 & 7.661 & -4.181 & 0.396 \\
\hline & & \multicolumn{4}{|c}{ Source: the authors }
\end{tabular}

Table 3 shows descriptive analysis of selected variables (company size, sales revenues, earnings before interest and taxes, current liquidity, debt, financial stability and profitability) for 3456 firms from the tourism sector in AP Vojvodina. Based on descriptive analysis, we can see that observed companies are liquid, with average current liquidity ratio 1.95. Also, observed firms had mean profitability level of $3.4 \%$, while average values of debt and financial stability are below 1 . This means that these companies do not have problems with debt and financial stability. Further, the highest standard deviation is identified at variables SIZE, EBIT and CL, which implies the largest oscillations in values for the selected period 2015-2019. 
Table 4 Correlation matrix

\begin{tabular}{l|c|c|c|c|c|c|c}
\hline Var. & ROA & SIZE & SR & EBIT & CL & DBT & FS \\
\hline ROA & 1.000 & $0.364^{*}$ & $0.359^{*}$ & $0.212^{*}$ & $-0.158^{*}$ & $-0.223^{*}$ & $0.135^{*}$ \\
\hline SIZE & $0.364^{*}$ & 1.000 & $0.086^{*}$ & 0.032 & $0.077^{*}$ & -0.001 & 0.027 \\
\hline SR & $0.359^{*}$ & $0.086^{*}$ & 1.000 & $0.123^{*}$ & $-0.064^{*}$ & -0.163 & 0.002 \\
\hline EBIT & $0.212^{*}$ & 0.032 & $0.123^{*}$ & 1.000 & $-0.037^{*}$ & $-0.051^{*}$ & 0.249 \\
\hline CL & $-0.158^{*}$ & $0.077^{*}$ & $-0.064^{*}$ & $-0.037^{*}$ & 1.000 & $-0.518^{*}$ & $0.086^{*}$ \\
\hline DBT & $-0.223^{*}$ & -0.001 & -0.163 & $-0.051^{*}$ & $-0.518^{*}$ & 1.000 & $-0.099^{*}$ \\
\hline FS & $0.135^{*}$ & 0.027 & 0.002 & 0.249 & $0.086^{*}$ & $-0.099^{*}$ & 1.000 \\
\hline
\end{tabular}

Table 4 presents the correlation between explanatory variables for companies from the tourism sector in AP Vojvodina. The results of correlation analysis show a statistically significant relationship between internal factors such as firm size, sales revenue, EBIT, liquidity, debt and financial stability and profitability measured by return on assets. Analysing the character of their relationship, we can see that company size, sales revenue, EBIT and financial stability are positively correlated with profitability, while the relationship between liquidity, debt and profitability is negative.

The application of the model should reveal how internal factors affect the profitability of companies from the tourism sector in AP Vojvodina. In order to ensure adequate modelling, it is necessary to perform testing potential multicollinearity, heteroscedasticity and model specification.

Table 5. Validity tests of model specification

\begin{tabular}{l|c|c}
\hline Variable & VIF & /VIF \\
\hline SIZE & 1.11 & 0.887 \\
\hline SR & 1.36 & 0.726 \\
\hline EBIT & 1.02 & 0.981 \\
\hline CL & 1.38 & 0.727 \\
\hline DBT & 1.01 & 0.988 \\
\hline FS & 1.36 & 0.726 \\
\hline $\begin{array}{l}\text { Mean VIF } \\
\text { test }\end{array}$ & 1.21 \\
\hline $\begin{array}{l}\text { Breusch-Pagan/Cook-Weisberg } \\
\text { test }\end{array}$ & Chi2 (1) $=0.32$ \\
\hline \multicolumn{2}{l|}{} & Prob > chi2 $=0.148$ \\
\hline \multicolumn{2}{l}{ Ramsey RESET test } & F $(3,3447)=3.04$ \\
\hline
\end{tabular}

Source: the authors

The results of multicolinearity, heteroscedasticity and model specification show that the presented model is adequately developed. The average value of VIF test is 1.21 , which means that there is no problem of multicolinearity between selected variables. Also, the results of $\mathrm{BP} / \mathrm{CW}$ test manifest that the null hypothesis about residual heteroscedasticity as well as the presence of a serial correlation between observed variables can be rejected. Finally, the results of the RR test demonstrate that regression model is properly specified since the value is above 0.05 .

Table 6. Multiple regression model

\begin{tabular}{|c|c|c|c|c|c|c|}
\hline Source & SS & df & MS & \multicolumn{2}{|c|}{$\begin{array}{l}\text { Number of } \\
\text { observations }\end{array}$} & 456 \\
\hline Model & 51.492 & 5 & $\begin{array}{c}10.29 \\
8\end{array}$ & \multicolumn{2}{|c|}{$\mathrm{F}(5,3450)$} & 72.15 \\
\hline $\begin{array}{l}\text { Residu } \\
\text { al }\end{array}$ & 492.440 & 3450 & 0.143 & \multicolumn{2}{|c|}{ Prob > F } & 0.000 \\
\hline Total & 543.932 & 3455 & 0.157 & \multicolumn{2}{|c|}{ R-squared } & 0.494 \\
\hline 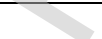 & & & & \multirow{2}{*}{\multicolumn{2}{|c|}{ Adj R-squared }} & 0.487 \\
\hline & & & & & & 0.378 \\
\hline ROA & Coef. & $\begin{array}{l}\text { Std. } \\
\text { Err. }\end{array}$ & $T$ & $P>|t|$ & \multicolumn{2}{|c|}{$\begin{array}{c}\text { [95\% Conf. } \\
\text { Interval] }\end{array}$} \\
\hline SIZE & 0.235 & $\begin{array}{c}0.03 \\
6 \\
\end{array}$ & 4.49 & $\begin{array}{c}0.00 \\
0\end{array}$ & 0.001 & 0.004 \\
\hline SR & 0.111 & $\begin{array}{c}0.00 \\
2\end{array}$ & 2.56 & $\begin{array}{c}0.00 \\
1\end{array}$ & 0.002 & 0.003 \\
\hline EBIT & 0.013 & $\begin{array}{c}0.00 \\
3\end{array}$ & 11.97 & $\begin{array}{c}0.00 \\
0\end{array}$ & 0.002 & 0.003 \\
\hline $\mathrm{CL}$ & -0.007 & $\begin{array}{c}0.00 \\
2 \\
\end{array}$ & 3.17 & $\begin{array}{c}0.00 \\
2 \\
\end{array}$ & 0.003 & 0.011 \\
\hline DBT & -0.256 & $\begin{array}{c}0.02 \\
6 \\
\end{array}$ & -9.61 & $\begin{array}{c}0.00 \\
0\end{array}$ & -0.307 & -0.203 \\
\hline FS & 0.001 & $\begin{array}{c}0.00 \\
3\end{array}$ & 0.44 & $\begin{array}{c}0.65 \\
9\end{array}$ & 0.004 & 0.007 \\
\hline $\mathrm{C}$ & 0.271 & $\begin{array}{c}0.02 \\
1\end{array}$ & 13.02 & $\begin{array}{c}0.00 \\
0\end{array}$ & 0.229 & 0.311 \\
\hline
\end{tabular}

Note: return on assets - ROA, company size - SIZE, sale revenues - SR, earnings before interest and taxes - EBIT, current liquidity $-C L$, debt $-D B T$, financial stability $-F S$

Source: the authors

The results of multiple regression model show that all explanatory variables, except variable FS, have a statistically significant impact on profitability of firms from the tourism sector in AP Vojvodina. Namely, variables SIZE, SR and EBIT have a positive effect on the ROA of observed firms, while CL and DBT negatively affect the profitability level measured by ROA. Analysing the intensity of the impact, the change in variables SIZE and DEBT leads to the largest change in ROA during the observed period. More 
precisely, the growth of variable SIZE by $1 \%$ causes an increase in ROA by $0.23 \%$, where higher level of debt by $1 \%$ leads to decrease in ROA by $0.26 \%$. Further, the growth of variables such as SR and EBIT by $1 \%$ increase profitability by $0.11 \%$ and $0.01 \%$ respectively. On the other side, if firms increase liquidity level by $1 \%$, their profitability will be smaller by $0.07 \%$.

\section{Conclusion}

The subject of paper includes the analysis of tourist sector in AP Vojvodina for the period 2015-2019. The tourism sector covers sector 55 (accommodation) and sector 56 (servicing and preparing food, beverages) and includes 3456 firms. The sector 56 (accommodation) covers 3148 firms or $91.09 \%$ of the total number of observed firms, while sector 55 (servicing and preparing food and beverages) covers 308 firms or $8.91 \%$ of the total number of analysed firms. This research implies descriptive analysis of profitability of the observed firms during last five years. Also, correlation analysis and multiple regression are applied in order to identify potential relationship between internal factors and profitability, as well as their effects on business success. It can be noticed that firms from tourist sector were profitable, where average ROA was $1.81 \%$. Further, the results revealed that firms from sector 56 were more profitable with average ROA of $3.56 \%$ and average ROE of $1.93 \%$. The correlation analysis shows a statistically significant relationship between internal factors such as firm size, sales revenue, EBIT, liquidity, debt and financial stability and return on assets as a proxy for profitability. Results of multiple regression model show that growth of firm size by $1 \%$ increases profitability by $0.23 \%$. Similarly, sales revenue and earnings before interest and taxes affect profitability positively. On the other hand, debt and liquidity have negative impact on profitability, where their growth by $1 \%$ decreases profitability by $0.26 \%$ and $0.07 \%$. These results confirm interdependence between liquidity and profitability, where higher level of liquidity implies lower profitability. The contribution of this paper is to enable IT support to management of firms in tourism sector, whose internal factors are significant for profitability level in the tourism sector.sm

\section{Acknowledgement}

The paper is a result of work on the project "Projection of financial operations of the tourism sector in AP Vojvodina in the function of sustainable development" - short-term project of special interest for sustainable development in AP Vojvodina in 2020.

\section{References}

Agiomirgianakis, G. M., Magoutas, A., \& Sfakianakis, G. (2013). Determinants of profitability in the Greek tourism sector revisited: The impact of the economic crisis. Journal of Tourism and Hospitality Management, 1(1), 12-17.

Alarussi, A. S., \& Alhaderi, S. M. (2018). Factors affecting profitability in Malaysia. Journal of Economic Studies, 45(3), 442-458. https://doi.org10.1108/jes-05-2017-0124

Andrašić, J., Mijić, K., Mirović, V., \& Kalaš, B. (2018). The modelling factors of agricultural companies performances, Custos e @gronegócio on line, 14(4), 223-240.

Bazargani, R.H.Z., \& Kiliç, H. (2021). Tourism competitiveness and tourism sector performance: Empirical insights from new data. Journal of Hospitality and Tourism Management, 46, 73-82. https://doi.org/10.1016/j.jhtm.2020.11.011

Ben Aissa, S., \& Goaied, M. (2016). Determinants of Tunisian hotel profitability: The role of managerial efficiency. Tourism Management, 52, 478-487. https://doi10.1016/j.tourman.2015.07.015

Dimitrić, M., Tomas Živković, I., \& Blecich, A.A. (2019). Profitability determinants of hotel companies in selected Mediterranean countries. Economic Research Ekonomska istraživanja, 32(1), 1977-1993. https://doi.org/10.1080/1331677X.2019.1642785

Dimitropoulos, P. E. (2017). Profitability determinants of the Greek hospitality industry: the crisis effect. Springer Proceedings in Business and Economics, 405-416. https://doi.org10.1007/978-3-319-67603-6 31

Kalaš, B., Mirović, V., \& Pavlović, N. (2019). Profitability determinants of hotel industry in AP Vojvodina. In Modern Management Tools and Economy of Tourism Sector in Present Era (47-62). Association of Economists and Managers of the Balkans-UDEKOM https://doi.org/10.31410/tmt.2019.47

Lado-Sestayo, R., Otero-González, L., Vivel-Búa, M., \& Martorell-Cunill, O. (2016). Impact of location on profitability in the Spanish hotel sector. Tourism Management, 52, 405-415 https://doi.org/10.1016/j.tourman.2015.07.011

Lado-Sestayo, R., \& Vivel-Búa, M. (2018). Profitability in the hotel sector: a PLS approach. Journal of Hospitality and Tourism Technology, 9(3), 455-470. https://doi.org10.1108/ihtt-10-2017-0118

Macas Nunes, P. J., Serrasqueiro, Z. M., \& Sequeira, T. N., (2009). Profitability in Portuguese service industries: A panel data approach. The Service Industries Journal, 29(5), 693-707 https://doi.org10.1080/02642060902720188

Markus, Z., Perovic, Dj., Pekovic, S., \& Popovic, S. (2019). Assessing Tourist Revisit Intention Through the Sports and Recreational Services Offered, Business Systems Research, 10(2), 141-150.

https://doi.org/10.2478/bsri-2019-023 
Menicucci, E. (2018). The influence of firm characteristics on profitability. International Journal of Contemporary Hospitality Management, 30(8), 1-25. https://doi.org10.1108/ijchm-04-2017-0219

Mijić, K., \& Jakšić, D. (2017). Indebtedness of Enterprises and Profitability Improvement. Strategic Management, 22(2), 36-40.

Milenković, N., Andrašić, J., \& Kalaš, B. (2017). Finansijska analiza sektora turizma-primer ugostiteljskih preduzeća severa Vojvodine. In Modern Management Tools and Economy of Tourism Sector in Present Era (197-212). Association of Economists and Managers of the Balkans-UDEKOM.

Moric, I., Pekovic, S., Vukčević, J., Perović, Đ., \& Grisbeck, M. (2021). Cultural Tourism and Community Engagement: Insight from Montenegro, Business Systems Research, 12(1), 164-178 https://doi.org/10.2478/bsri-2021-0011

Pavković, V., Jević, G., Jević, J., Nguyen, P.T., \& Sava, C. (2021). Determining efficiency of tourism sector in certain European countries and regions by applying DEA analysis. Journal of Process Management and New Technologies, 9(3-4), 49-61. https://doi.org/10.5937/jpmnt9-34122

Pavlović, N., \& Đeri, L. (2016). The importance of operations of tourism SME's for regional development of Vojvodina. Tourism International Scientific Conference Vrnjačka Banja - TISC, 1(2), 169-186. Retrieved from https://www.tisc.rs/proceedings/index.php/hitmc/article/v iew/180

Provincial Secretariat for Economy and Tourism (2018). Tourism development program in the Autonomus Province Vojvodina for the period from 2018 to 2022. Provincial Government, Autonomus Province of Vojvodina

\section{$\triangle$ Correspondence}

\section{Branimir Kalaš}

Faculty of Economics in Subotica

Segedinski put 9-11, 24000, Subotica, Serbia

E-mail: branimir.kalas@ef.uns.ac.rs
Rodríguez-Díaz, R., \& Rodríguez-Díaz, M. (2018). Special incentives for rehabilitation of tourism destinations to improve the profitability of accommodations: the case of the Canary Islands. Sustainability, 10(6), 1-20 https://doi.org/10.3390/su10061953

Sharpley, R. (2020). Tourism, sustainable development and the theoretical divide: 20 years on. Journal of Sustainable Tourism, 11, 1-15 https://doi.org/10.1080/09669582.2020.1779732

Skuflić, L., \& Mlinarić, D., (2015). Microeconomic determinants of profitability for Croatian hotel industry]. Ekonomski Pregled, 66(5), 477-494. https://hrcak.srce.hr/147869

Stierwald, A. (2010). Determinants of firm profitabilityDeterminants of profitability: An analysis of large Australian firms. Melbourne Institute Working Paper No. 3/10, SSRN Electronic Journal https://doi.org/10.2139/ssrn.1632749

Tan, Y. (2017). Hotel-specific, industry-specific and macroeconomic determinants of profitability in London hotel industry: Structure-conduct-performance or efficient-structure hypothesis? SSRN Electronic Journal. Retrieved from https://ssrn.com/abstract $=2943487$

Usmani, G., Akram, V., \& Praveen, B. (2020). Tourist arrivals, international tourist expenditure, and economic growth in BRIC countries. Journal of Public Affairs, 21(1), 1-8

https://doi.org/10.1002/pa.2202 